\title{
Hydrogeophysical investigation of groundwater potential and aquifer vulnerability prediction in basement complex terrain - A case study from Akure, Southwestern Nigeria
}

\author{
Hidrogeofizikalna raziskava potenciala in napovedovanje ranljivosti \\ podzemnega vodonosnika na območju stare geološke podlage - \\ primer raziskave v Akureju v jugozahodni Nigeriji
}

\section{Opeyemi J. Akinrinade *, Rasheed B. Adesina}

Department of Marine Science and Technology, Federal University of Technology Akure, Nigeria

*ojakinrinade@futa.edu.ng

\begin{abstract}
This study provides a model for the prediction of groundwater potential and vulnerability of basement aquifers in parts of Akure, Southwestern Nigeria. Hydrogeophysical surveys involving very-low-frequency electromagnetic (VLF-EM) profiling and electrical resistivity (ER) sounding, as well as evaluation of hydraulic gradient using three-point method, were carried out. Ten VLF-EM reconnaissance survey traverses, with lengths ranging from $55 \mathrm{~m}$ to $75 \mathrm{~m}$, at $10 \mathrm{~m}$ station separation, and 12 vertical electrical sounding (VES) stations were occupied. Two-dimensional map of the filtered real component reveals areas of high conductivity, indicative of linear features that can serve as a reservoir or conduit for fluid flow. Interpretation of the VES results delineates three to four geoelectric units. Two aquifer zones were identified, with resistivity values in the ranges of $20 \Omega \mathrm{m}$ to $310 \Omega \mathrm{m}$ and $100 \Omega \mathrm{m}$ to $3,000 \Omega \mathrm{m}$, respectively. Transverse resistance, longitudinal conductance, coefficient of anisotropy and hydraulic gradient have values ranging from $318.2 \Omega \mathrm{m}^{2}$ to $1,041.8 \Omega \mathrm{m}^{2}, 0.11 \mathrm{mhos}$ to $0.39 \mathrm{mhos}, 1.04$ to 1.74 and 0.017 to 0.05 , respectively. The results of this study identified two prospective borehole locations and the optimum position to site the proposed septic system, based on the aquifer's protective capacity and groundwater flow properties.
\end{abstract}

Key words: aquifer vulnerability, basement aquifer, contamination, geophysical methods, groundwater flow

\section{Izvleček}

Pričujča študija je primer ugotavljanja potenciala podtalnice in ocene ranljivosti vodonosnika v geološki podlagi na območju Akure v jugozahodni Nigeriji. Opravili so hidrogeofizikalno raziskavo z uporabo zelo nizkofrekvenčnega elektromagnetnega (Very Low Frequency Electromagnetic, VLF-EM) profiliranja, električno odpornostnega (Electrical Resistivity, ER) sondiranja in določanja hidravličnega gradienta po metodi treh točk. Izmerili so deset prospekcijskih profilov VLF-EM dolžine od $55 \mathrm{~m}$ do 75 m, z 10-metrskim razmakom med postajami in dvanajst postaj VES. Na 2D karti filtrirane realne komponente je videti območja visoke prevodnosti, ki nakazujejo prisotnost linearnih struktur, kakršne lahko služijo kot rezervoar ali pa kanal za pretok tekočin. Interpretacija rezultatov VES kaže tri ali štiri geoelektrične enote. Ugotovili so dve vodonosni coni, prva z upornostjo od $20 \Omega \mathrm{m}$ do $310 \Omega \mathrm{m}$ in druga od $100 \Omega \mathrm{m}$ do 3,000 $\Omega \mathrm{m}$. Transverzalna upornost se giblje med $318,2 \Omega \mathrm{m}^{2}$ in $1,041,8 \Omega \mathrm{m}^{2}$, vzdolžna prevodnost med 0,11 mho in 0,39 mho, koeficient anizotropnosti med 1,04 in 1,74 ter hidravličnega gradienta med 0,017 in 0,05 . Po rezultatih te študije so locirali dve raziskovalni vrtini in optimalno lego septične kanalizacije glede na zaščitno zmogljivost vodonosnika in lastnosti pretakanja podtalnice.

Ključne besede: ranljivost vodonosnika, vodonosnik v stari podlagi, onesnaženje, geofizikalne metode, tok podtalnice 


\section{Introduction}

Groundwater is a valuable, indispensable and vulnerable natural resource, which should be explored and used to build a database for efficient management and land-use planning $[1,2]$. This is important because increasing demand for potable water occasioned by the ever-increasing population, inability of major city dams to meet demands, and collapse of many public water systems have led to increase in groundwater abstraction for domestic use. Generally, groundwater provides a reasonable constant supply and possesses excellent quality that requires little or no treatment in most cases [3]. Excessive abstraction of groundwater from neighbourhood boreholes and hand-dug wells sometimes stresses the hydrogeologic system and alters the groundwater flow pattern. Moreover, groundwater is vulnerable to contamination from anthropogenic sources, which is transmitted in the direction of flow. Hydrogeophysical investigation adopts nonintrusive geophysical methods to investigate drillable prospects and characterise reservoir properties. Electrical resistivity (ER) and very-low-frequency electromagnetic (VLFEM) methods have been extensively applied in groundwater investigation, determination of depth to bedrock and analysis of superficial deposits in basement complex terrains. The VLFEM technique has proven useful, effective and efficient in detecting long, straight, electrical conductors, identifying viable drillable groundwater exploitation sites and locating fractures [4-6]. Compared with many other geophysical methods, as a reconnaissance tool, it provides a cost-effective and relatively fast approach to delineate fractures in the shallow subsurface. The ER method using vertical electrical sounding (VES) field procedure has often been used in routine groundwater exploration both in alluvial and hard rock environment [7-9].

Aquifers in basement complex environments are located in the weathered layer or fractured bedrock [10-15]. Aquifer properties that influence groundwater flow include transmissivity, hydraulic conductivity and homogeneity of the materials that constitute the internal architecture of the aquifer [16]. Evaluation of the hydraulic gradient, as well as the flow rate and direction of the associated groundwater, is a fundamental aspect of hydrogeologic characterisation. Hydrogeologic investigations therefore focus on these aquifers as targets for drillable prospects. Generally, basement rocks have low permeability and porosity, properties that influence their electrical properties [6, 17]. Identifying viable groundwater exploitation sites should take into consideration potential pollution sources that can easily affect the groundwater system and transmit the contamination to wider areas. Hence, knowledge of groundwater flow properties is required to make holistic predictions and suggest remediation for possible pollution.

The likelihood of groundwater contamination by the subsurface sewage disposal system is high, especially in areas wherein septic systems are closely spaced and bedrock is covered by little or no soil $[2,18]$. If septic systems are located in sensitive areas or are poorly built, they can cause pollution of water supplies and the environment. In addition, improper waste handling has in many cases resulted in serious groundwater contamination [19]. Effluents discharged to the subsurface by drain fields often percolate into the same aquifer tapped by wells for domestic supply. This pollution can have serious environmental and economic implications [20]. However, because the soil acts as a natural filter, effluents from septic systems can be prevented from seeping into the underlying aquifer [21] depending on the aquifer's protective capacity, as indicated by the longitudinal unit conductance value $[22,23]$.

Thus, groundwater exploitation, environmental impact assessment and site's spatial development planning are interrelated. The aim of this study is to identify drillable groundwater prospects and determine the optimum location to site a proposed septic system.

\section{Physiography and geology of the study area}

The study area is bounded by latitudes $7^{\circ} 17^{\prime} 14.45^{\prime \prime} \mathrm{N}$ and $7^{\circ} 17^{\prime} 17.64^{\prime \prime} \mathrm{N}$ and longitudes $5^{\circ} 9^{\prime} 09.04^{\prime \prime} \mathrm{E}$ and $5^{\circ} 9^{\prime} 11.94^{\prime \prime} \mathrm{E}$. It is located in Alaba Layout, near the Federal University of Technology, Akure (FUTA), Ondo State, 


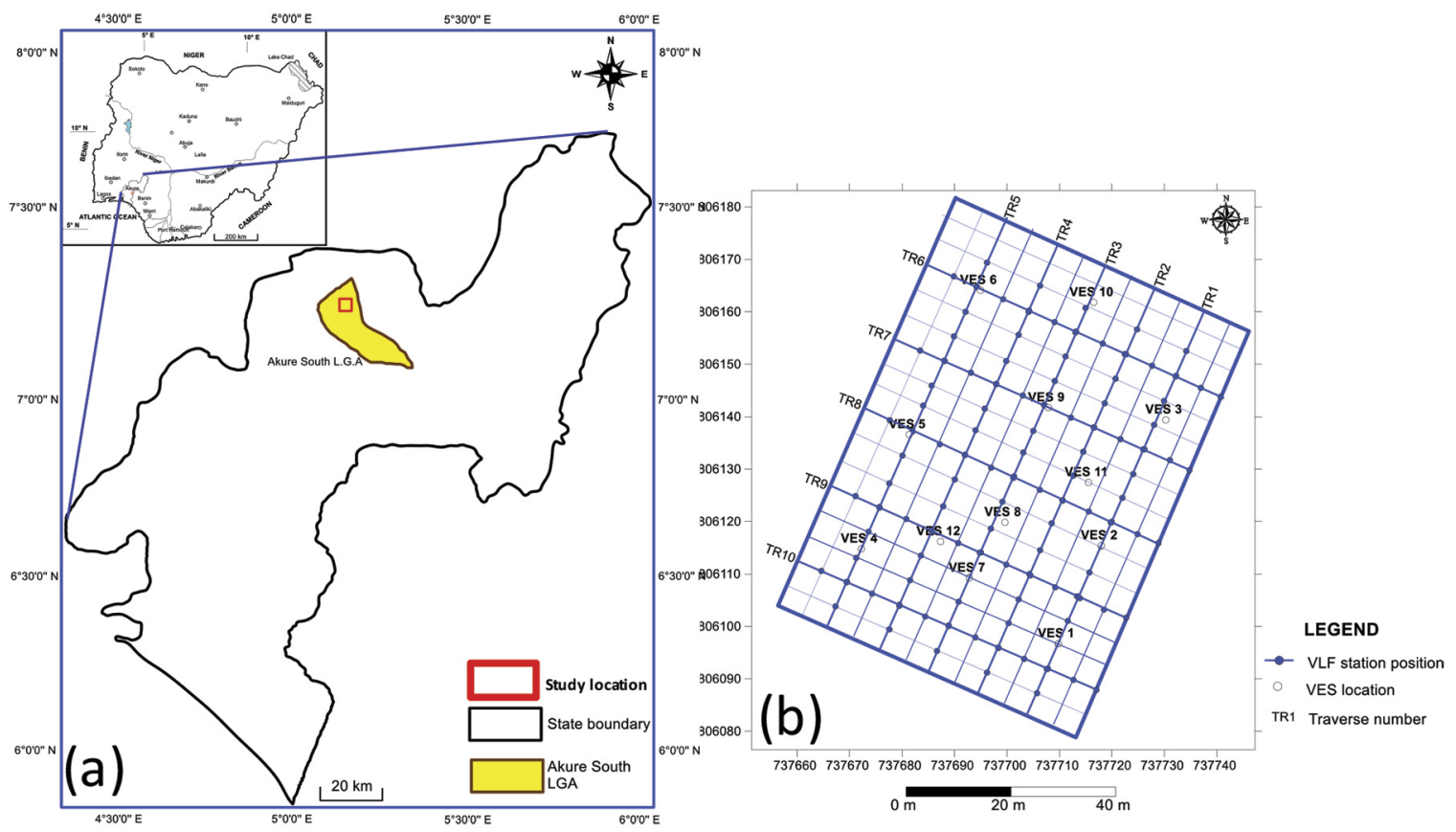

Figure 1: (a) Map of Ondo State indicating the study area (inset is the map of Nigeria). (b) Field survey layout for the study with outlined traverses, station positions and VES locations.

Southwestern Nigeria (Figure 1), and is accessible by footpaths and secondary roads from FUTA South Gate. The site is located on a gently undulating terrain, with average topographical elevation of $364 \mathrm{~m}$ above sea level. Sources of potable water for inhabitants of the area are hand-dug wells and boreholes drilled for domestic uses. The area is densely populated because of its nearness to the University. Akure area, which is located in the tropics, has a mean annual rainfall between $1,250 \mathrm{~mm}$ and $1,500 \mathrm{~mm}$ and relative humidity between $50 \%$ and $80 \%$ [24]. The vegetation cover in the area is sparse due to its dense population and nearness to the University.

The area is underlain by crystalline basement rocks [25], with charnockite being a prominent lithologic unit (Figure 2). Generally, fractured bedrock occurs in a typical basement terrain in tropical and equatorial regions, while weathering processes create superficial layers, with varying degrees of porosity and permeability. Omosuyi et al. [26] show that unconsolidated overburden could constitute a reliable aquifer if significantly thick. In addition, the basement rock may be associated with other geological structures that indicate zones of weakness for groundwater accumu- lation. These structures may house abundant groundwater in a typical basement setting. The detection and delineation of such structural features may facilitate the location of groundwater prospect zones.

\section{Materials and methods}

VLF-EM and direct current (DC) ER methods were used in this study. Carefully selected tools, which include ABEM WADI VLF EM equipment, Ohmega resistivity metre with associated accessories and Garmin Global Positioning System, were used for data acquisition. Survey planning was carried out using satellite imagery of the site obtained from Google Earth ${ }^{\circledR}$. Ten VLF profiles were occupied during the reconnaissance survey. The profile length varied from $55 \mathrm{~m}$ to $70 \mathrm{~m}$, with station separation of $5 \mathrm{~m}$ (Figure 3). The result of the reconnaissance survey assisted in selection of suitable VES points. Twelve VES stations were occupied using the Schlumberger electrode configuration. Data processing and modeling were carried out using Karous-Hjelt filter ${ }^{\circledR}$, Win-Resist ${ }^{\circledR}$ and Surfer ${ }^{\circledR}$. The results of this study are presented in Figures 1-8 and Tables 1 and 2. 


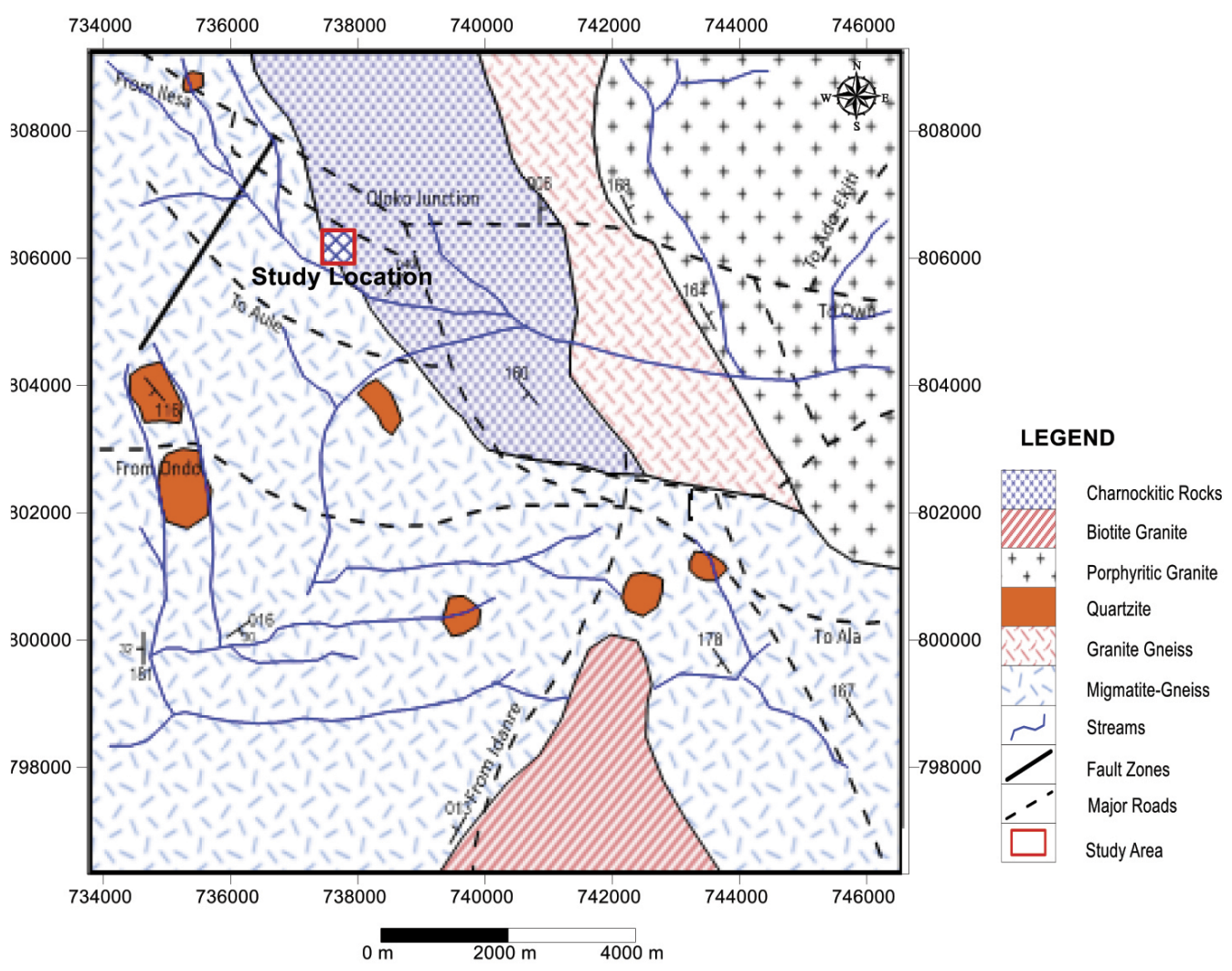

Figure 2: The study area identified on a simplified geological map of Akure [27].

\section{VLF-EM method}

The VLF method operates on the principle of EM induction, which is based on the measurement of ground response to an EM force that propagates through it. This is made up of both the alternating electric field intensity and the magnetising force. When the primary field from a transmitter strikes a body, a secondary field is generated by the body. The difference between the primary (transmitter) and the secondary fields (induced current flow within the subsurface electrical conductor) defines the nature and structure of the body. VLF-EM transmits in the frequency range of $15-25 \mathrm{KHz}$. The main magnetic field component is horizontal and theoretically is tangential to circles concentric about the antenna mast. Raw real, filtered real (FR), raw imaginary and filtered imaginary components of the EM signal were recorded during data acquisition. The VLF-EM method does not require contact with the ground and can be deployed easily, thereby saving time as compared with some other geophysical methods. The Karous-Hjelt filter ${ }^{\circledR}$ was used in data processing to enhance the signal-to-noise ratio, such that tilt-angle crossovers will be easier to identify [28]. The filter also converts tilt-angle crossovers into peaks and calculates the equivalent source current at a given depth, which is known as the current density. The current density assists in the interpretation of the width and dip of a fracture as a function of depth. The FR component was gridded to create a two-dimensional map of its distribution over the study area.

\section{ER method}

The DC-ER method involves the introduction of current into the subsurface through current electrodes and measurement of the potential difference with the aid of potential electrodes. The VES field procedure involves increasing the electrode array about a fixed center in order to probe deeper subsurfaces and determine the variations in resistivity with depth. The Schlumberger electrode configuration was adopted, with $100 \mathrm{~m}$ being the maximum current electrode separation $(A B / 2)$, while the maximum potential electrode separation was 10 m (MN/2). Dar Zarrouk (second-order geo- 

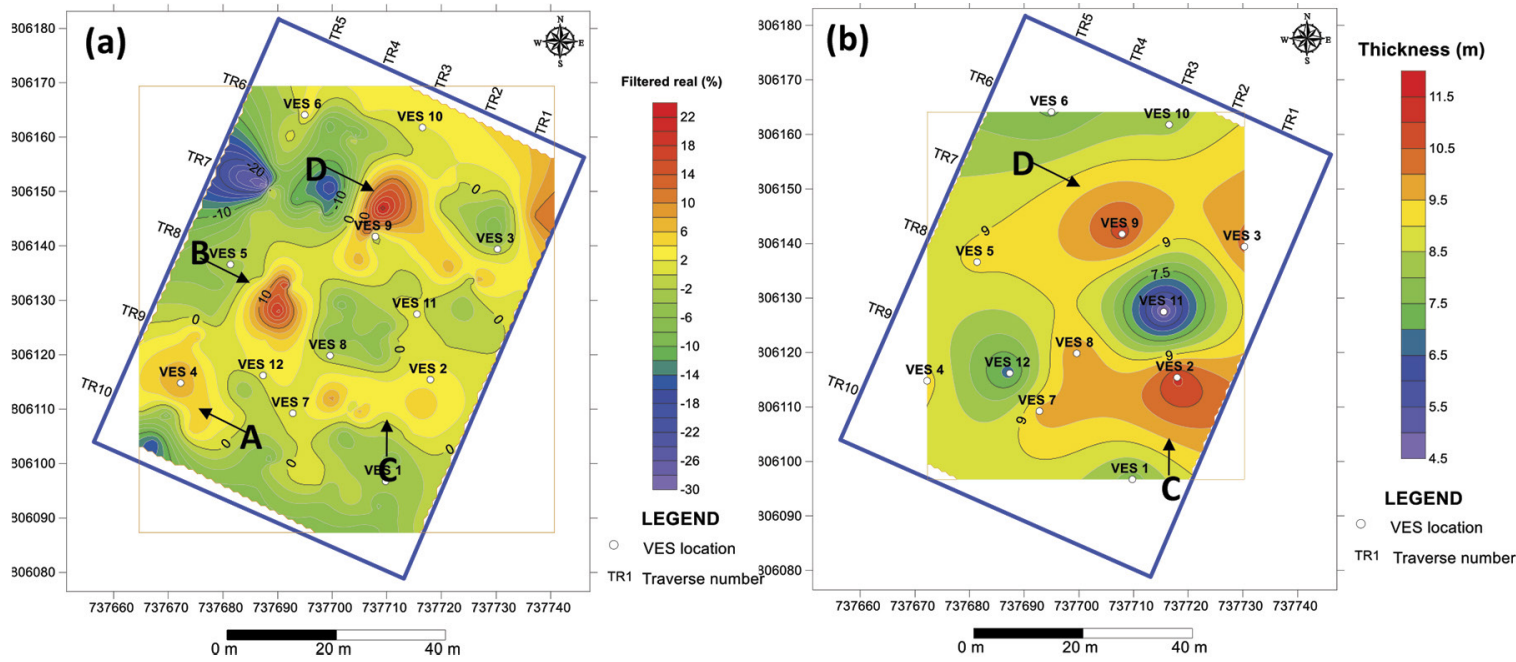

Figure 3: (a) Filtered real VLF-EM anomaly map. (b) Overburden thickness map.
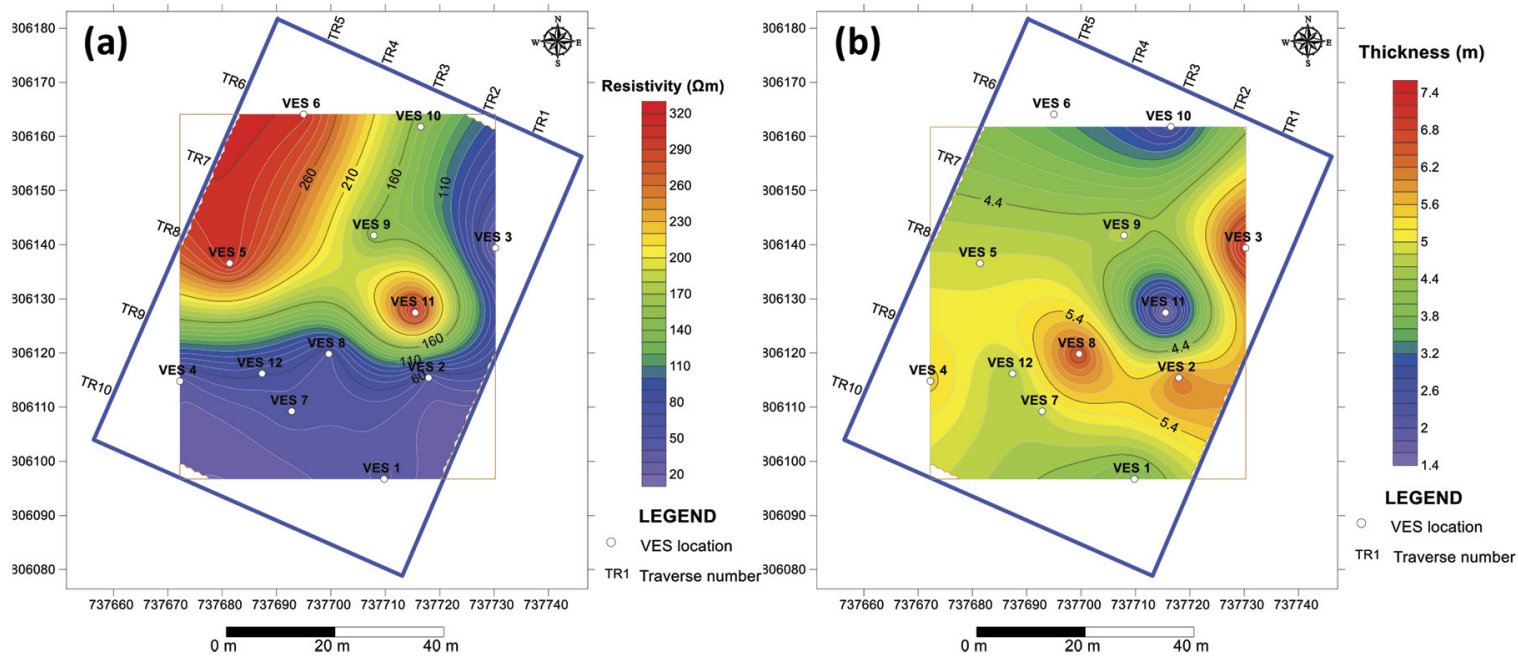

Figure 4: (a) Isoresistivity map of the weathered layer (third geoelectric unit). (b) Weathered layer thickness map.
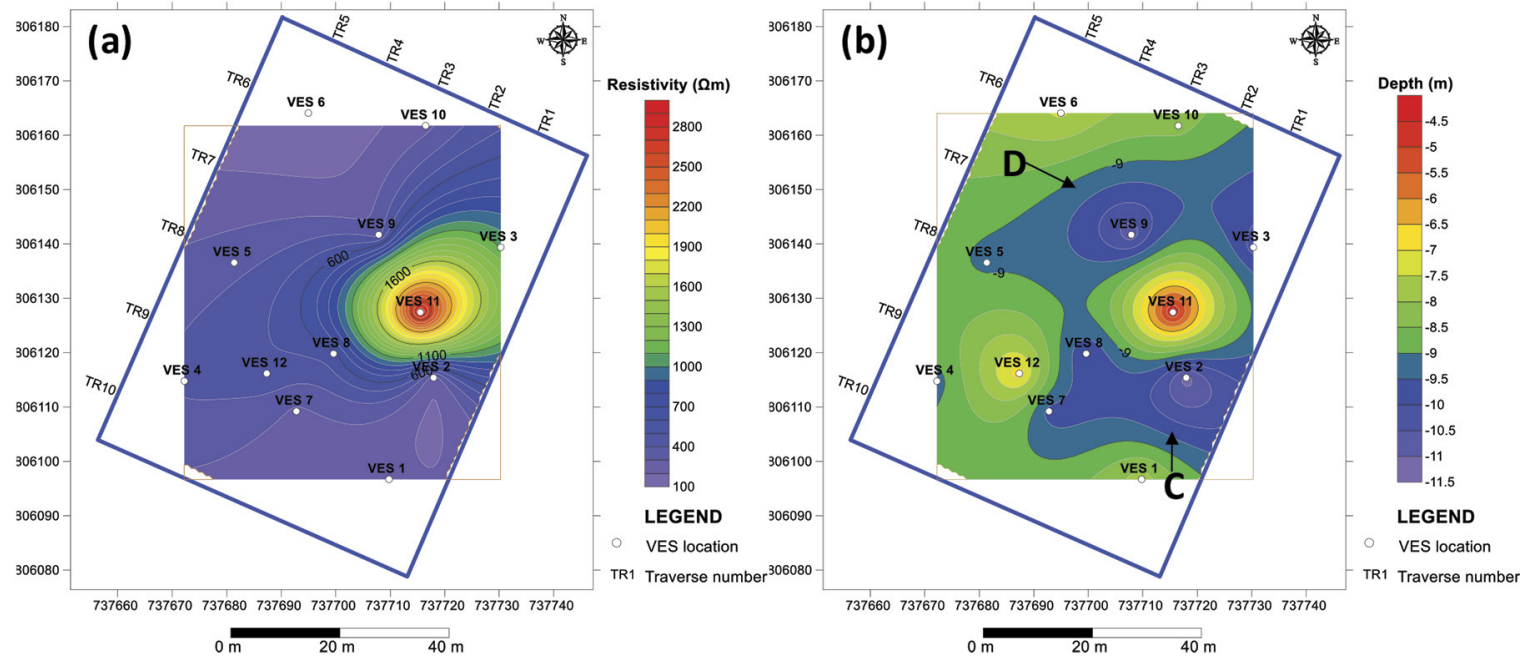

Figure 5: (a) Isoresistivity map of the bedrock. (b) Bedrock relief map of the area. 


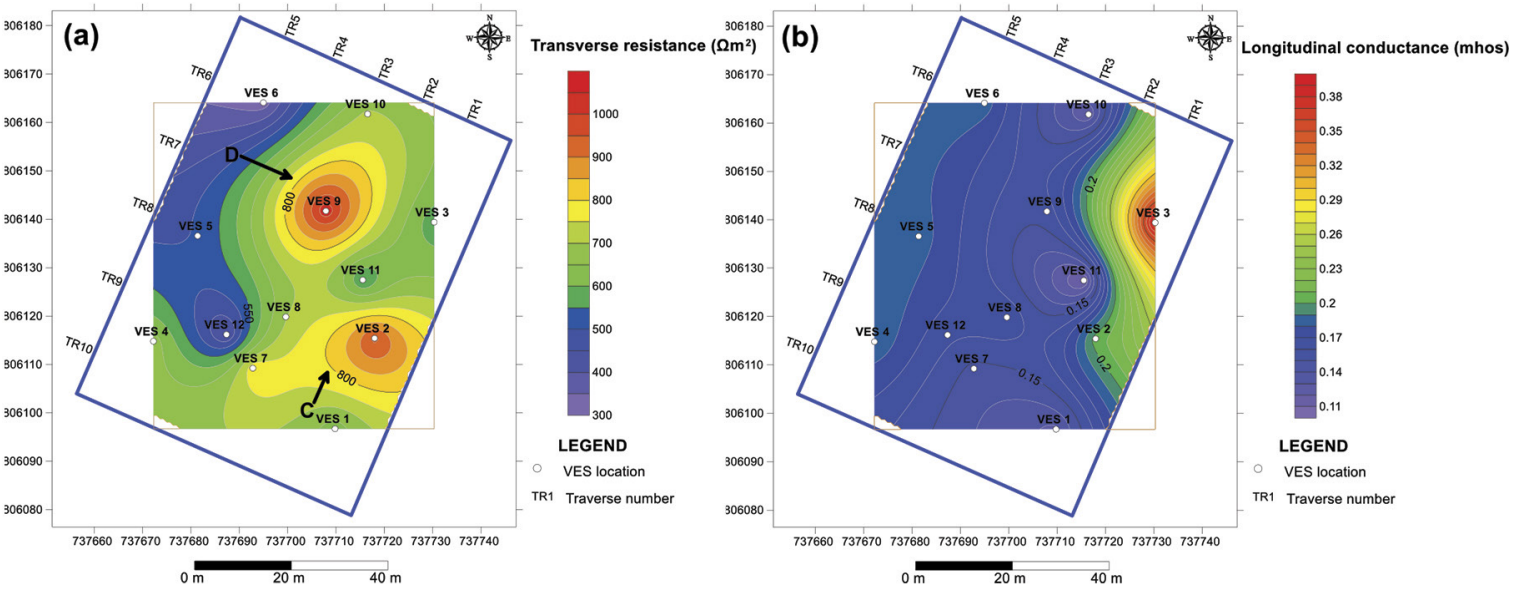

Figure 6: (a) Transverse unit resistance map. (b) Longitudinal unit conductance map.
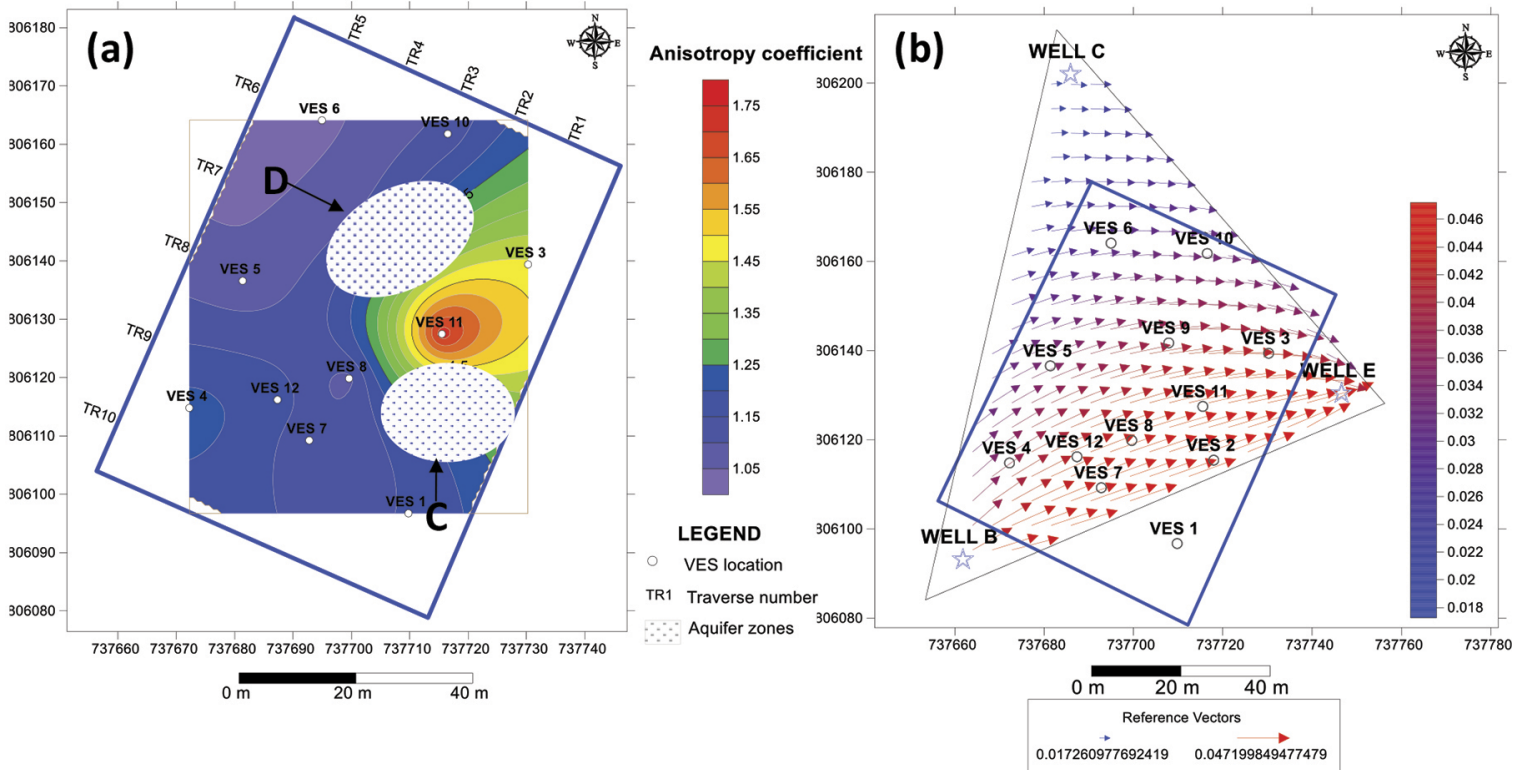

Figure 7: (a) Coefficient of anisotropy map. (b) Hydraulic gradient vector plot of groundwater flow magnitude and direction.

electric) parameters were determined from primary geoelectric parameters, namely, layer resistivity (r) and thickness $(h)$ values.

\section{Determination of hydraulic gradient}

The three-point method of determining the hydraulic gradient was adopted. The water table elevation of hand-dug wells at three locations was subtracted from the surface elevation at each well location. The differences in elevation divided into equal increments over the horizontal distance separating the wells were used to generate the vector plot of groundwater flow magnitude and direction [29]. This represents the hydraulic gradient at the study site.

\section{Results and discussion}

\section{Interpretation of FR VLF-EM results}

The FR VLF-EM anomalies have values that range between -30 and 23 . The high positive anomalies are representative of fluid-filled linear structures, such as faults and fractures, at the study site. These serve as conduits and potential reservoirs for groundwater accumulation and are therefore possible groundwater exploitation targets (Figure 3a). The site is characterised by a central, relatively low anomaly, with values that range between -10 and -2 . This anomaly is surrounded by regions with relatively higher values oriented in the northeast- 


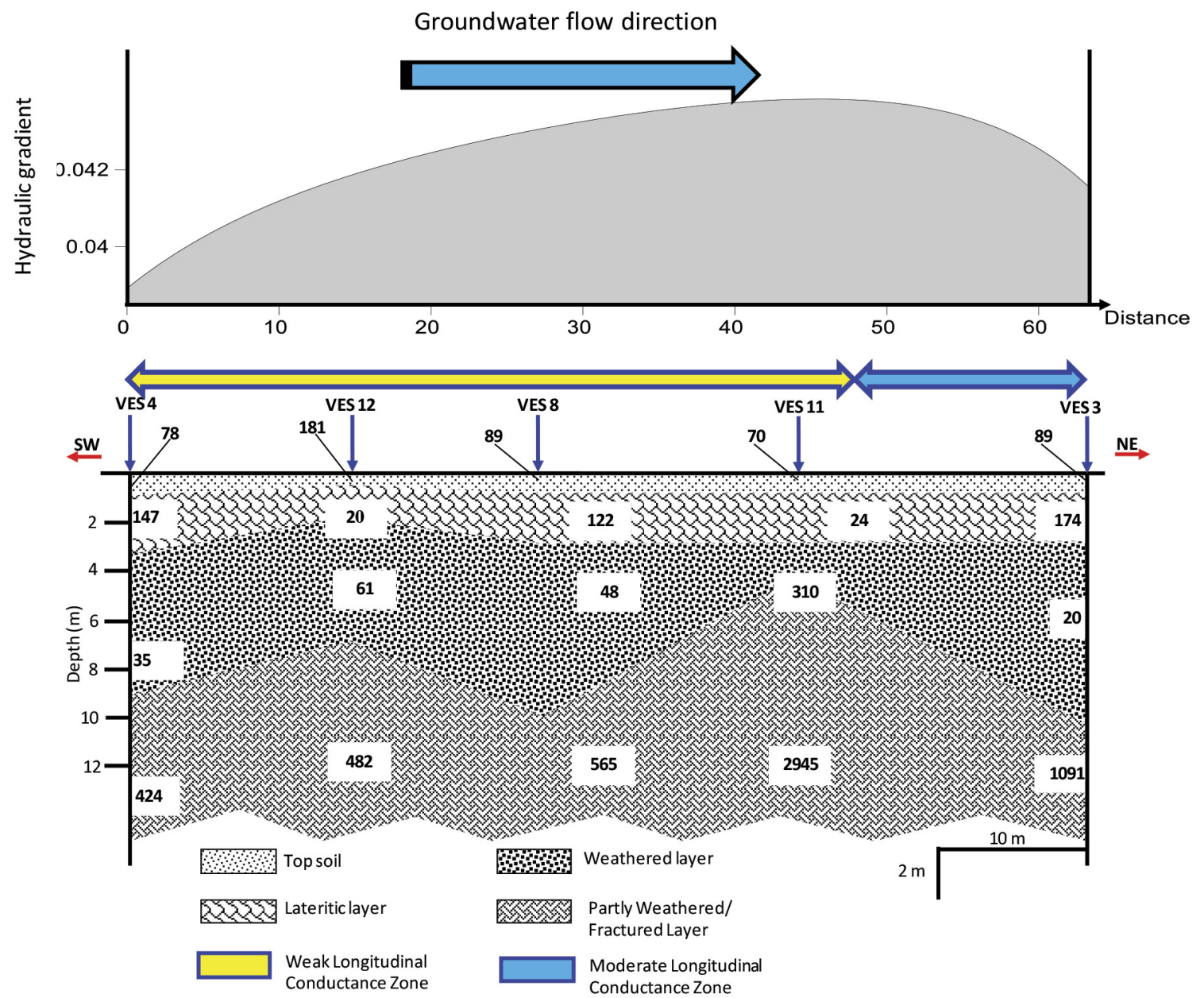

Figure 8: Profile of hydraulic gradient and geoelectric section along an arbitrary profile, integrated with the longitudinal unit conductance.

southwest direction. A relatively low anomaly is observed on the western and southeastern flanks, which extends toward the center, with the zero value as the bounding contour. From this reconnaissance survey, four distinctive closures characterised by high FR values were identified as potential targets for groundwater exploitation (Figure 3a).

\section{Geoelectric interpretation}

From the interpretation of the modelled geoelectric curves, overburden thickness maps (Figure 3b), as well as isoresistivity and layer thickness maps, of the weathered layer were generated (Figure $4 \mathrm{a}$ and $4 \mathrm{~b}$ ). The overburden thickness values ranged from $4.3 \mathrm{~m}$ to $11.1 \mathrm{~m}$. Low overburden thickness characterises the eastern flank, which is surrounded by a thick overburden with values $>8.5 \mathrm{~m}$. This characteristic is similar to that revealed by the re- connaissance survey using VLF-EM. It is therefore deduced that areas with high overburden thickness are associated with high positive FR anomaly and are therefore potential groundwater reservoirs. From this result, two zones were identified as potential groundwater exploitation sites. These are points $C$ and $D$, which have the highest overburden thickness values and are connected with point B (Figure 3b). The ER method using VES has good correlation with the VLF-EM method in delineating areas suitable for groundwater exploitation.

Weathered layer resistivity values ranged from $20 \Omega \mathrm{m}$ to $310 \Omega \mathrm{m}$ (Figure $4 \mathrm{a}$ ). Generally, the weathered layer resistivity value is low and is representative of highly weathered, fractured, and/or fluid-saturated geoelectric units. The thickness ranges from $1.4 \mathrm{~m}$ to $7.4 \mathrm{~m}$ (Figure 4b). Relatively thick overburden surrounds the structure at VES11, interpreted as shallow 
Table 1: Summary of geoelectric and Dar Zarrouk parameters over the study area.

\begin{tabular}{|c|c|c|c|c|c|c|c|c|c|c|}
\hline $\begin{array}{l}\text { VES } \\
\text { Station }\end{array}$ & $\begin{array}{l}\text { No. } \\
\text { of } \\
\text { layers }\end{array}$ & $\begin{array}{l}\text { Resistivity } \\
(\mathrm{Ohm}-\mathrm{m}) \rho_{1 / \rho_{2} / . . \rho_{\mathrm{n}-1}}\end{array}$ & $\begin{array}{l}\text { Curve } \\
\text { Type }\end{array}$ & $\begin{array}{l}\text { Thickness }(m) \\
h_{1} / h_{2} / h_{3}\end{array}$ & $\begin{array}{l}\text { Depth }(m) \\
d_{1} / d_{2} / \ldots d_{n-1}\end{array}$ & $\begin{array}{c}\text { Transverse } \\
\text { resistivity } \\
(\Omega \mathrm{m})\end{array}$ & $\begin{array}{l}\text { Longitudinal } \\
\text { resistivity } \\
(\Omega \mathrm{m})\end{array}$ & $\begin{array}{c}\text { Transverse } \\
\text { resistance } \\
\left(\Omega \mathrm{m}^{2}\right)\end{array}$ & $\begin{array}{c}\text { Longitudinal } \\
\text { Conductance } \\
\text { (mhos) }\end{array}$ & $\begin{array}{l}\text { Anisotropy } \\
\text { Coefficient }\end{array}$ \\
\hline 1 & 4 & $54 / 139 / 43 / 235$ & $\mathrm{KH}$ & $1.0 / 2.9 / 3.8$ & $1.0 / 3.9 / 7.7$ & 80.58 & 60.27 & 620.5 & 0.1278 & 1.1563 \\
\hline 2 & 4 & $44 / 170 / 39 / 220$ & $\mathrm{KH}$ & $1.0 / 4.0 / 6.1$ & $1.0 / 5.0 / 11.1$ & 86.23 & 54.57 & 965.8 & 0.2052 & 1.2570 \\
\hline 3 & 4 & $89 / 174 / 20 / 1091$ & $\mathrm{KH}$ & $0.8 / 2.0 / 7.4$ & $0.8 / 2.8 / 10.2$ & 55.61 & 26.12 & 567.2 & 0.3905 & 1.4590 \\
\hline 4 & 4 & $78 / 147 / 35 / 424$ & $\mathrm{KH}$ & $0.9 / 2.8 / 5.5$ & $0.9 / 3.6 / 9.1$ & 73.29 & 49.01 & 674.3 & 0.1877 & 1.2229 \\
\hline 5 & 3 & $100 / 43 / 307$ & $\mathrm{H}$ & $2.0 / 7.1$ & $2.0 / 9.1$ & 55.53 & 49.16 & 505.3 & 0.1851 & 1.0628 \\
\hline 6 & 3 & $73 / 36 / 304$ & $\mathrm{H}$ & $1.4 / 6.0$ & $1.4 / 7.4$ & 43.00 & 39.82 & 318.2 & 0.1858 & 1.0392 \\
\hline 7 & 4 & $53 / 123 / 48 / 280$ & $\mathrm{KH}$ & $0.7 / 4.2 / 4.8$ & $0.7 / 5.0 / 9.7$ & 80.84 & 65.83 & 784.1 & 0.1474 & 1.1081 \\
\hline 8 & 4 & $89 / 122 / 48 / 565$ & $\mathrm{KH}$ & $0.8 / 2.5 / 6.7$ & $0.8 / 3.3 / 10.0$ & 69.78 & 59.15 & 697.8 & 0.1691 & 1.0862 \\
\hline 9 & 4 & $109 / 45 / 151 / 357$ & $\mathrm{HA}$ & $0.9 / 5.2 / 4.7$ & $0.9 / 6.1 / 10.9$ & 96.46 & 69.71 & 1041.8 & 0.1549 & 1.1764 \\
\hline 10 & 4 & $89 / 50 / 148 / 269$ & $\mathrm{HA}$ & $1.3 / 4.5 / 2.5$ & $1.3 / 5.6 / 8.3$ & 85.63 & 68.31 & 710.7 & 0.1215 & 1.1196 \\
\hline 11 & 4 & $70 / 24 / 310 / 2945$ & $\mathrm{HA}$ & $0.8 / 2.2 / 1.4$ & $0.8 / 2.9 / 4.3$ & 123.36 & 40.89 & 542.8 & 0.1076 & 1.7370 \\
\hline 12 & 4 & $181 / 20 / 61 / 482$ & $\mathrm{HA}$ & $0.4 / 1.7 / 4.6$ & $0.4 / 2.1 / 6.8$ & 57.76 & 41.20 & 387 & 0.1626 & 1.1840 \\
\hline
\end{tabular}

Table 2: Parameters required for determination of hydraulic gradient using three-point method.

\begin{tabular}{cccc} 
& $\begin{array}{c}\text { Elevation } \\
\text { Above } \\
\text { Mean Sea } \\
\text { Level (m) }\end{array}$ & $\begin{array}{c}\text { Hydraulic } \\
\text { Head (m) }\end{array}$ & $\begin{array}{c}\text { Depth to } \\
\text { water table } \\
\text { (m) }\end{array}$ \\
\hline WELL B & 365.6 & 359.6 & 6 \\
\hline WELL C & 360.6 & 357.67 & 2.93 \\
\hline WELL E & 356.7 & 355.39 & 1.31 \\
\hline
\end{tabular}

bedrock. This structure has similar structural configuration as that identified by the FR VLF anomaly and overburden thickness maps (Figure $3 \mathrm{a}$ and $3 \mathrm{~b}$ ) and can serve as a potential groundwater exploitation target.

The bedrock resistivity values range from $100 \Omega \mathrm{m}$ to $3,100 \Omega \mathrm{m}$ (Figure 5a). A major part of this layer is characterised by resistivity values between $100 \Omega \mathrm{m}$ and $1,000 \Omega \mathrm{m}$, which is representative of highly weathered, fractured and fluid-saturated basement rock. The high resistivity values obtained on the eastern flank show protruding bedrock relief, with similar signatures identified in the VLE-EM map (Figure 3a). The bedrock relief map (Figure $5 b$ ) reveals an undulating topography, with shallow basement rock around VES11 on the eastern flank; which is surrounded by a deep chan- nel-like structure. This is similar to the structure identified on the FR VLF-EM map (Figure $3 a)$. The northern and southern flanks of this structure reveal a synclinal structure, which is a possible groundwater reservoir for exploitation. The deepest parts of the basement rock, indicated as points C (around VES2) and D (around VES9), are therefore favourable targets for groundwater exploitation (Figure 5b). From the above observations, differential weathering occasioned by fluid saturation is evident in this site. Thus, VLF-EM and VES are complementary tools that give good correlation in delineating bedrock relief and associated structures that are favourable for groundwater exploitation.

\section{Characterisation of aquifer parameters}

Transverse unit resistance, longitudinal unit conductance and anisotropy coefficient maps produced were used to characterise the properties of the delineated aquifers (Table 1). Transverse unit resistance values range from $318 \Omega \mathrm{m}^{2}$ to $1,042 \Omega \mathrm{m}^{2}$ (Figure 6a). Regions around VES2 and VES9 are characterised by relatively high transverse unit resistance values, while a low value pattern is observed on the northwestern flank. Zones with high transverse unit resistance values are characterised 
as areas with high recharge capability and thus render them the best groundwater exploitation targets in the area. This observation further corroborates the results obtained from the FR VLF-EM conductivity map and basement relief structures of potential groundwater reservoirs (Figure 5b). Relating the potential reservoir area extent and recharge ability, it is observed that reservoir around VES2 has a larger surface area but relatively lower recharge ability compared with the reservoir around VES9 (Figure $6 a)$. Based on the results obtained, either of the two reservoirs is recommended for groundwater exploitation.

Longitudinal conductance values estimated from the first-order parameters have values that range from 0.11 mhos to 0.39 mhos (Figure 6b). Generally, the site is characterised by longitudinal unit conductance values that increase from the western flank to the eastern flank. Using aquifer protective capacity classification for basement terrains [22-23], the site is characterised as of medium-to-low protective capacity. The delineated groundwater exploitation locations are characterised by low protective capacity, which therefore makes the delineated aquifers susceptible to potential pollution.

Anisotropy coefficient maps (Figure 7a) reveal the degree of homogeneity that characterises the subsurface earth materials and associated fluid content within the study area. The anisotropy coefficient values obtained range from 1.04 to 1.74 . The eastern flank is characterised by high anisotropy coefficient values, which is attributed principally to the influence of the shallow bedrock and adjacent fluid-saturated reservoirs (Figure 7a). However, the northwestern flank exhibits a low anisotropy coefficient, which extends southward through the center. The prospective groundwater exploitation sites identified are characterised by relatively low anisotropy coefficient values, which implies that the materials are relatively homogeneous.

\section{Groundwater flow modelling}

The hydraulic gradient (Figure 7b) was computed using the hydraulic head (Table 2) obtained from three hand-dug wells around the study site. Vector plot of the hydraulic gradient revealed the magnitude and direction of the groundwater flow in the study area. The gen- eral trend reveals that groundwater flows eastward. The energy of the flow, as deduced from the reference vector, shows that the hydraulic gradient is higher in the southern flank than in the northern flank. Thus, if the groundwater becomes contaminated, transmission of such contaminants will be faster on the southwestern flank than in the northern flank. However, because the protective capacity is generally low on the site, the most reliable location to situate the proposed septic system is the eastern flank with moderate protective capacity. By implication, spatial development of the site requires proper consideration of the location of the septic system and wastewater transmission channels such that the influence of the leachate will not contaminate the groundwater system. The eastern flank beyond VES3, characterised by high longitudinal unit conductance values, proves to be the most appropriate (Figure 8), because the highly weathered layer with resistivity of $20 \Omega \mathrm{m}$ and thickness of $7.4 \mathrm{~m}$ can provide the natural filtering required to prevent contamination from reaching the groundwater system. The cumulative impact of contamination over time is considered in the selection.

\section{Integrated model of geoelectric and hydraulic properties}

Review of the site's spatial development plan, groundwater potential and possible location of septic system is carried out in order to prevent effluent flow, which could contaminate the identified aquifers. These results present the overview of hydrogeology and hydrogeophysical techniques in development planning and groundwater resources management. Construction of an arbitrary geoelectric profile (Figure 8) along the northeast-southwest direction was considered to determine a two-dimensional subsurface sequence of the identified geoelectric units in relation to the hydraulic gradient, in order to evaluate the spatial development plan. The northeastern flank is characterised by a weathered layer with relatively low values of resistivity, transverse resistivity and longitudinal resistivity $(20 \Omega \mathrm{m}$, $55.6 \Omega \mathrm{m}$ and $26.1 \Omega \mathrm{m}$, respectively). The geoelectric properties of the weathered layer at the eastern flank thus buttresses the suitability of the location for the septic system. Groundwater 
exploitation requires a comprehensive review of the groundwater potential using integrated geophysical methods, as well as potential environmental impact implications.

\section{Conclusion}

Groundwater resources management and spatial development planning require a thorough review of all available information. The VLFEM method serves as a vital reconnaissance tool before deploying the ER method for detailed investigation. These methods function as complementary tools, reduce uncertainties in subsurface exploration and assist in determining the most reliable location for groundwater exploitation.

The delineated aquifers are characterised by relatively thick overburden $(>9.5 \mathrm{~m})$ and high transverse unit resistance, indicating relatively high recharge rate, but overlain by materials of generally weak protective capacity (0.110.39 mhos) and relatively high anisotropy coefficient (1.04-1.74). Integrated interpretation of the geoelectric and hydraulic properties identified the optimum location to site the proposed septic system to prevent contamination of the aquifer.

This study reveals the need for comprehensive evaluation of a site's spatial development plan, taking into consideration the hydrogeological conditions and possible impact of such activity. This further elaborates on the groundwater exploration techniques in difficult terrains and the need for policies to protect such resources. Detailed hydrogeological and hydrogeophysical investigations should be carried out prior to borehole drilling, in order to prevent contamination by effluents from anthropogenic sources, which percolates into the subsurface.

\section{Acknowledgements}

The authors thank Dr. A. Y. B. Anifowose of the Department of Remote Sensing and Geoscience Information System and the anonymous reviewer for their thorough review of this work and general advice.

\section{References}

[1] Wattanasen, K., Elming, S. (2008): Direct and indirect methods for groundwater investigations: A case study of MRS and VES in the Southern part of Sweden. Journal of Applied Geophysics, 66, pp. 104-117.

[2] Eze, C. L., Eze, E. M. (2015): Investigation of possible groundwater contamination from septic system siting in Port Harcourt, Nigeria. Journal of Natural Sciences Research, 5(10), pp. 83-87.

[3] Asiwaju-Bello, Y. A., Olabode, F. O., Duvbiama, O. A., Iyamu, J. O, Adeyemo, A. A., Onigbinde, M. T. (2013): Hydrochemical evaluation of groundwater in Akure Area, Southwestern Nigeria, for irrigation purpose. European International Journal of Science and Technology, 2(8), pp. 235-249.

[4] Hutchinson, P. J., Barta. L. S. (2002): VLF surveying to delineate longwall mine induced fractures. Leading Edge, pp. 491-493.

[5] Olorunfemi, M. O., Fatoba, J. O., Ademilua, L. O. (2005): Integrated VLF-electromagnetic and electrical resistivity survey for groundwater in a crystalline basement complex terrain of Southwest Nigeria. Global Journal of Geological Sciences, 3(1), pp. 71-80.

[6] Bayewu, 0. O., Oloruntola, M. O., Mosuro, G. O., Watabuni, F. G. (2012): Groundwater exploration in Ago-Iwoye Area of Southwestern Nigeria, using Very Low Frequency Electromagnetic (VLF-EM) and electrical resistivity methods. International Journal of Applied Sciences and Engineering Research, 1(3), pp. 452-462. doi: 10.6088/ijaser.0020101046

[7] Yadav, G. S., Singh, P. N., Srivastava, K. M. (1997): Fast method of resistivity sounding for shallow groundwater investigations. Journal of Applied Geophysics, 36, pp. $45-52$.

[8] Sundararajan, N., Nandakumar, G., Chary, M. N., Ramam, K. Srinivas, Y. (2007): VES and VLF-an application to groundwater exploration, Khammam, India. The Leading Edge, pp. 708-716.

[9] Muchingami, I., Hlatywayo, D. J., Nel, J. M., Chuma, C. (2012): Electrical resistivity survey for groundwater investigations and shallow subsurface evaluation of the basaltic-greenstone formation of the urban $\mathrm{Bu}$ lawayo aquifer. Physics and Chemistry of the Earth, 50-52, pp. 44-51.

[10] Odusanya, B. O., Amadi, U. M. P. (1990): An empirical resistivity model for predicting shallow groundwater in the Basement Complex Water Resources. Journal of Nigeria Association of Hydrogeologists, 2, pp. 77-87.

[11] Olayinka, A. I., Olorunfemi, M. O. (1992): Determination of geoelectrical characteristics in Okene area and 
implication for borehole siting. Journal of Mining and Geology, 28, pp. 403-412.

[12] Olorunfemi, M. O., Fasuyi, S. A. (1993): Aquifer types and the geoelectric/hydrogeological characteristics of part of the central basement terrain of Nigeria (Niger State). Journal of African Earth Sciences, 16(3), pp. 309-316.

[13] Dan-Hassan, M. A., Olorunfemi, M. O. (1999): Hydro-geophysical investigation of a basement terrain in the north central part of Kaduna State, Nigeria. Journal of Mining and Geology, 35(2), pp. 189-206.

[14] Adepelumi, A. A., Akinmade, O. B., Fayemi. O. (2013): Evaluation of groundwater potential of Baikin Ondo State, Nigeria using resistivity and magnetic techniques: a case study. Universal Journal of Geoscience, 1(2), pp. 37-45.

[15] Akinrinade, O. J., Olabode, O. P. (2015): Integrated geophysical approach to aquifer delineation in crystalline basement environment. International Journal of Scientific and Engineering Research (IJSER), France, 6(10), pp. 107-127.

[16] Harb, N., Haddad, K., Farkh, S. (2010): Calculation of transverse resistance to correct aquifer resistivity of groundwater saturated zones: implications for estimating its hydrogeological properties, Lebanese Science Journal, 11(1), pp. 105-115.

[17] Hutchinson, P. J., Beird, M. H., Mitchell, M. (2010): Groundwater purveying using very low frequency fracture delineation methods. Proceedings from the 2010 Symposium on the Application of Geophysics to Engineering and Environmental Problems, pp. 294-301. http://geo-image.com/documents/30.pdf

[18] Hanchar, D. W. (1991): Effects of septic-tank effluent on groundwater quality in northern Willianson County and southern Davidson County, Tennessee. Water Resources Investigations Report 91-4011, US Geological Survey.

[19] Panagiotakis, I., Dermatas, D., Vatseris, C., Chrysochoou, M., Papassiopi, N., Xenidis, A., Vaxevanidou, K. (2015): Forensic investigation of a Chromium VI groundwater plume in Thiva, Greece. Journal of Hazardous Materials, 281, pp. 27-34.

[20] Banda, L. J., Mbewe, A. R., Nzala, S. H., Halwindi, H. (2014): Effect of siting boreholes and septic tanks on groundwater quality in St. Bonaventure Township of Lusaka District, Zambia. International Journal of En- vironmental Sciences Toxic Research, 2(9), pp. 191198.

[21] McQuillain, D. (2004): Ground-Water Quality Impacts From On-Site Septic Systems. Proceedings of 13th Annual Conference on National Onsite Wastewater Recycling Association, Albuquerque, New Mexico, pp. 1-13.

[22] Henriet, J. P. (1976): Direct application of the Dar Zarrouk parameters in groundwater surveys. Geophysics Prospective, 24, pp. 344-353.

[23] Oladapo, M. I., Mohammed, M. Z., Adeoye, O. O., Adetola, B. A. (2004): Geoelectric investigation of the Ondo State Housing Corporation Estate, Ijapo Akure, southwestern Nigeria. Journal of Mining and Geology, 40(1), pp. 41-48.

[24] Iloeje, N. P. (1981): A New Geography of Nigeria (New revised edition). Longman Nigeria Limited, Lagos, p. 201.

[25] Rahaman, M. A. (1976): Review of the basement geology of southwestern Nigeria. In Geology of Nigeria, C. A. Kogbe (Ed.), Elizabethan Publishers, Lagos, pp. 41-58.

[26] Omosuyi, G. O., Adegoke, A. O., Adelusi, A. O. (2008): Interpretation of Electromagnetic and Geoelectric Sounding Data for Groundwater Resources around Obanla-Obakekere, near Akure, Southwestern Nigeria. Pacific Journal of Science and Technology, 9(2), pp. 509-525.

[27] Owoyemi, F. B. (1996): A Geological-Geophysical Investigation of Rain-Induced Erosional Features in $A k$ ure Metropolis. Unpublished M.Tech Thesis, Federal University of Technology Akure, Nigeria, pp. 11-18.

[28] Karous, M., Hjelt, S. E. (1983): Linear filter of VLF dip-angle measurements. Geophysical Prospecting, 31, pp. 782-794.

[29] Poehls, D. J., Smith, G. J. (2009): Encyclopedic Dictionary of Hydrogeology. Elsevier Academic Research Incorporation, Amsterdam, ISBN 978-0-12-558690-0, p. 518. 
